\title{
Differential Expression of Leptin and Leptin Receptor mRNA in Obese and Non-Obese Women across the Menstrual Cycle Title
}

\author{
María-Raquel Huerta-Franco' 1 E. R. Huerta-Franco'2 , F. M. Vargas-Luna ${ }^{3}$ \\ ${ }^{1}$ Department of Sciences Applied to the Work, University of Guanajuato, Leon, México \\ ${ }^{2}$ Department of Dentistry, University of Guadalajara, Guadalajara, México \\ ${ }^{3}$ Department of Physical Engineering, University of Guanajuato, Leon, México \\ Email: huertafranco@hotmail.com
}

Received 24 September 2014; revised 17 November 2014; accepted 6 December 2014

Copyright (C) 2014 by authors and Scientific Research Publishing Inc.

This work is licensed under the Creative Commons Attribution International License (CC BY). http://creativecommons.org/licenses/by/4.0/

(c) (i) Open Access

\begin{abstract}
OBJECTIVE: The aim of this study was to investigate the messenger ribonucleic acid expression of leptin (L-mRNA) and the leptin receptor (OB-RmRNA) in subcutaneous fat tissue and to determine their relationship with leptin and testosterone and steroid serum levels over the course of the menstrual cycle (MC), in obese (OBW) and non-obese women (NOW). DESIGN: Observational study investigating mRNA transcript expression of leptin and the leptin receptor from human subcutaneous fat specimens, as well as leptin serum levels, both in relation to the testosterone and sex hormones during the MC in obese and non-obese women. METHODS: Nineteen women, thirteen with a body mass index (BMI) $\geq 25 \mathrm{Kg} / \mathrm{m}^{2}$ and 6 with $\mathrm{BMI}<25 \mathrm{Kg} / \mathrm{m}^{2}$ were included. RT-PCR was used to detect L-mRNA transcripts of leptin and its receptor in samples from 28 fat biopsies taken from seven volunteers ( 20 from $0 W$ and 8 from NOW). The serum concentrations of leptin and steroid hormones were measured throughout the MC using radioinmuno analysis. RESULTS: The percentages of women expressing leptin L-mRNA during the phases of the MC were: early follicular (EF), 14.3\%; late follicular (LF), 28.6\%; early luteal (EL), 14.3\%; and late luteal (LL), 42.9\%. The percentages of OB-RmRNA were: EF, 71.4\%; LF, 14.3\%; EL, 28.6\%; and LL, $71.4 \%$. Leptin serum levels were directly related to BMI $(p<0.001)$, and testosterone $(p<0.001)$ and indirectly to SHBG (p < 0.001). CONCLUSION: The L-mRNA expression and its receptor in subcutaneous human tissue are regulated throughout the MC in a periodic manner. The physiological role of testosterone in regulation of expression L-mRNA and OB-RmRNA during the secretory phase of the MC in obese women requires further investigation.
\end{abstract}

\section{Keywords}

Steroid Hormones, Leptin, Leptin Receptor, Menstrual Cycle 


\section{Introduction}

It has been demonstrated that leptin, the product of the obese (ob) gene, which is synthesized and secreted exclusively by adipose tissue, provides a signal regulating the total mass of body fat [1]. In humans, serum leptin levels are correlated with the amount of body fat, body mass index (BMI), waist to hip (W/H) ratio, and with tricipital and sub-scapular skin fold thickness [2]. In addition to acting on metabolism, leptin has also been shown to be associated with reproductive alterations, which include findings that: 1) higher levels of leptin have been shown to be associated with an earlier onset of menarche [3]; 2) in women with polycystic ovary syndrome (PCOS), leptin levels are higher than those expected for the patient based on BMI [4]; 3) women have higher leptin levels during pregnancy than in the post-partum period (which could be associated with the amount of fat that accumulates during pregnancy) [5]. These effects of leptin are thought to be mediated mainly through brain leptin receptor, whose messenger ribonucleic acid is known as OB-R mRNA. However, leptin ribonucleic acid (L-mRNA) and OB-R mRNA are also expressed in peripheral tissues, including human endometrial tissue [6]. It is demonstrated that the expression of OB-R mRNA in human endometrial tissue during the menstrual cycle was greatest in the early secretory phase and declined during the mid and late secretory phases toward menstruation. However, Alfer et al. [7] demonstrated that leptin and long isoform of the leptin receptor are expressed in glands and luminal epithelium of the human endometrial tissue during the follicular and mid-secretory phases. These findings suggest that leptin and leptin receptor OB-R mRNAs are regulated by steroid sex hormones. The finding that the leptin receptor has been identified in peripheral tissues of the reproductive axis, in conjunction with the fact that higher amounts of leptin are found in obese subjects, led us to investigate the L-mRNA and OB-R mRNA expression of leptin and its receptor in subcutaneous fat tissue, as well as leptin serum levels over the course of the four phases of the menstrual cycle in both obese and non-obese women. Together, we believe that these data will help us to come to a better understanding of the relationship between leptin and OB-R mRNA expression and sex hormones, potentially allowing us to understand the interconnection of these two major homeostatic systems and identify if the relationship between them is one of causation or correlation.

\section{Subjects and Methods}

\subsection{Subjects}

A group of 19 women, aged 18 - 40 (mean: 30.7 years), was recruited after the protocol was approved by the Human Ethics Committee of the University of Guanajuato, México. Written informed consent was obtained from all participating subjects, and the study was conducted according to the Declaration of Helsinki criteria. Subjects were divided into two groups, one comprised of 13 overweight women (OW) with body mass index $(\mathrm{BMI}) \geq 25 \mathrm{Kg} / \mathrm{m}^{2}$ and the other with six non-overweight women (NOW), BMI $<25 \mathrm{Kg} / \mathrm{m}^{2}$. All subjects had history of regular menstrual cycles ( $>21$ and $<35$ days), were confirmed as capable of ovulation by testing for $\mathrm{P}_{4}>5 \mathrm{ng} / \mathrm{mL}$, during days 21 - 23 of the menstrual cycle, and did not suffer from diabetes or any other endocrine alterations.

\subsection{Protocol}

Height and weight were measured by standard procedures, and each subject's BMI was calculated. Waist circumferences were measured during the midinspiratory phase, midway between the xyphoid and the umbilicus. Hip measurements were taken at the maximum circumference of the hip area. Measurements were taken using a flexible measuring tape with a tension caliper. Skin fold thickness was measured at three different anatomical sites (triceps, suprailium, and thigh) using a Lange skinfold caliper (Cambridge Scientific Industries, Inc, Cambridge, MA. The percentage of body fat [BF(\%)] was determined according to methods previously described [8]

[9]. The nineteen subjects were evaluated four times during their menstrual cycle: early follicular (EF): days 1 to 4 from the last menstrual period (LMP); late follicular (LF): days 9 to 14 from the LMP; early luteal (EL): days 15 to 18, from the LMP; and late luteal (LL): days 23 to 28, from the LMP.

\subsection{Hormone Assay}

During each of the four phases of the menstrual cycle (EF, LF, EL and LL), a single $20 \mathrm{~mL}$ non-heparinized peripheral blood sample was obtained between the hours of 8:00 and 9:00 a.m. after a 10 - 12 hour period of over- 
night fasting. Plasma glucose concentrations were tested using a glucose oxidase assay (glucose analyzer, Bechman, Fullerton, $C A)$. Aliquots of fasting serum were frozen at $-70^{\circ} \mathrm{C}$. Analyses for estradiol $\left(\mathrm{E}_{2}\right)$, total testosterone $(\mathrm{T})$, progesterone $\left(\mathrm{P}_{4}\right)$, and insulin levels were carried out in duplicate with solid phase commercial RIAs (Diagnostic Products, Los Angeles, CA). Levels of follicle stimulating hormone (FSH), luteinizing hormone (LH), SHBG, and leptin were measured with a commercial double antibody system (Diagnostic Systems Laboratory, Inc, Webster, TX). The intra-assay coefficients of variation (CV) were $\leq 7 \%$ for both sex hormones and insulin, and were $<4 \%$ for leptin.

\subsection{Tissue Samples}

A total of 28 subcutaneous fat specimens were obtained via biopsy from seven women (24 OW and four NOW) with normal menstrual cycles and a proven history of fertility. Of these patients, six had achieved pregnancies and births (range 1 - 4 children). The 28 biopsies were taken throughout the menstrual cycle; one from each woman at each phase (EF, LF, EL and LL). Patients from which we could not obtain 4 samples were eliminated from the RT-PCR analysis. Adipose tissue samples were immediately frozen in liquid nitrogen and stored at $-70^{\circ} \mathrm{C}$ until tested.

\subsection{RT-PCR}

Total L-mRNA and OB-R mRNA expression from each sample was isolated using TriPureTM Isolation Reagent (Lakeside, Boehringer, Mannheim, Germany). The primer for the first-strand for cDNA synthesis was derived from the full length RNA transcript with oligo (dT) and SuperScript TM RNase H-Reverse Transcriptase (GibcoBRL, Life Technologies, NY, USA). To amplify specific products, leptin and leptin receptor-specific primers (20 pmol) were used. The primers used for PCRs were as follows: Leptin [10] (416 bp): 5'

ACCCTGTGCGGATTCTTGTGG 3'and 5'CTCTGTGGAGTAGCCTGAAGC 3'; leptin receptor [11] (273 bp): 5'CATTTTATCCCCATTGAGAAGTA 3' and 5'CTGAAAATTAAGTCCTTGTGCCCA 3'; $\boldsymbol{G D H}$ [12]: (521 bp) 5'GGTGAAGGTCGGAGTCAACGG 3', 5'GGTCATGAGTCCTTCCACGATACC 3' [12]. For PCR we used the GeneAmp ${ }^{\circledR}$ PCR reagent Kit with AmpliTaq ${ }^{\circledR}$ DNA polymerase (Perkin Elmer PCR Reagent. Branchburg, New Jersey, USA) and the following protocol: one cycle: [ $\left(7 \mathrm{~min}\right.$ at $94^{\circ} \mathrm{C} ; 1 \mathrm{~min}$ at $55^{\circ} \mathrm{C} ; 1.5 \mathrm{~min}$ at $\left.72^{\circ} \mathrm{C}\right), 35$ cycles: $\left(1 \mathrm{~min}\right.$ at $94^{\circ} \mathrm{C} ; 1 \mathrm{~min}$ at $55^{\circ} \mathrm{C} ; 1.5 \mathrm{~min}$ at $\left.72^{\circ} \mathrm{C}\right)$ and one cycle: $\left(1 \mathrm{~min}\right.$ at $94^{\circ} \mathrm{C} ; 1 \mathrm{~min}$ at $55^{\circ} \mathrm{C}$; $7 \mathrm{~min}$ at $72^{\circ} \mathrm{C}$ )]. Finally, PCR products were separated in a $2 \%$ agarose gel in a Tris-Borate-EDTA buffer (TBE), stained with ethidium bromide, and analyzed using densitometry for the presence of absence of an amplified product in the lane.

\subsection{Statistical Analysis}

A test of normality was carried out for each the variables studied and the following variables showed normal distribution: age, anthropometric data, and leptin serum levels. With the exception of leptin, pairs of hormone levels were compared using levels from the four phases of the menstrual cycle (EF, LF, EL and LL, respectively) using a Wilcoxon matched pair test. Leptin serum levels among different phases of the menstrual cycle were compared with a t-test for dependent samples. An ANOVA was used to compare leptin serum levels between OW and NOW. A step-wise multiple regression analysis was used to determine the correlation between leptin levels and anthropometric data, as well as between leptin levels and other hormone levels. Statistical analyses were performed with STATISTICA, Stat-Soft, Inc. Tulsa OK.

\section{Results}

The mean and SD for age, as well as the age of menarche for obese $(\mathrm{N}=13)$ and non-obese women $(\mathrm{N}=6)$, were: $28.5 \pm 5.9$ (mean \pm SD) vs. $21.2 \pm 4.2$ yr. and $11.8 \pm 0.93$ vs. $12.0 \pm 1$ yr, respectively. The length of the cycle and the number of days of menses during women's menstrual cycles were: $28.3 \pm 2.5$ vs. $28.7 \pm 1.2$; and $4.91 \pm 1.62$ vs. $4.0 \pm 1.0$ days for OW and NOW, respectively. In Table 1, we show that the weight and BMI of OW did not change significantly throughout the menstrual cycle. However, in NOW, weight and BMI increased significantly from the late follicular phase to the late luteal phase of the menstrual cycle. In OW, the percentage of body fat (BF-\%) increased from LF to EL and from LF to LL.

As was expected, $\mathrm{P}_{4}$ serum levels increased in early and late luteal phases of the menstrual cycle in both OW 
and NOW (as shown in Table 2).

In OW and NOW, SHBG serum levels were lower in LF than in the other phases of the menstrual cycle. Figure 1 shows the leptin serum levels in $\mathrm{ng} / \mathrm{mL}$ for OW and NOW in the four phases of the menstrual cycle: $12.32 \pm 3.6,12.4 \pm 3.6,12.7 \pm 4.0,13.3 \pm 3.2$ (for OW) vs. $7.42 \pm 2.3,7.74 \pm 3.8,8.54 \pm 3.31,8.5 \pm 3.7$ (for NOW), $\mathrm{F}=2.7, \mathrm{p}=0.02$, (EF, LF, EL and LL, respectively).

It is important to note that there are no significant differences in leptin levels among the phases of the menstrual cycle in OW. However, in NOW, it appears that leptin serum levels increase from follicular to the secretory phase of the menstrual cycle, but the statistical significance of this data is just above our convention for significance $(p=0.05)$, with a value of $p=0.07$. Multiple regression analysis showed that in OW, leptin serum levels were negatively correlated to SHBG $(p<0.001)$, and positively to testosterone $(p=0.03)$. A regression analysis of leptin levels in the different phases of the menstrual cycle demonstrated that leptin was directly

Table 1. Variations in weight, BMI, and percentage of body fat in obese (OW, $N=13)$ and non-obese women $(\mathrm{NOW}, \mathrm{N}=6)$ during the menstrual cycle: median (Minimum-Maximum).

\begin{tabular}{cccccc}
\hline & & \multicolumn{4}{c}{ Menstrual Cycle } \\
\cline { 3 - 6 } & & EF & LF & EL & LL \\
\hline \multirow{2}{*}{ Weight $(\mathrm{Kg})$} & OW & $72.8(66.6-103.7)$ & $72.1(65.3-103.3)$ & $71.6(65.4-103.4)$ & $72.8(66.6-103.7)$ \\
& NOW & $50.2(44.5-56.8)$ & ${ }^{*} 49.1(44.5-57.1)$ & $49.3(44.0-56.8)$ & ${ }^{*} 50.5(44.8-57.8)$ \\
BMI $\left(\mathrm{Kg} / \mathrm{m}^{2}\right)$ & OW & $30.1(26.0-38.5)$ & $30.0(25.5-38.1)$ & $29.4(25.5-38.5)$ & $29.7(25.6-38.2)$ \\
& NOW & $19.9(17.8-22.2)$ & ${ }^{*} 19.6(17.8-22.3)$ & ${ }^{*} 20.2(17.9-22.6)$ & $19.9(17.8-22.2)$ \\
BF $(\%)$ & OW & ${ }^{*} 34.6(25.2-40.5)$ & ${ }^{*} 32.7(23.7-39.2)$ & ${ }^{*} 33.2(28.0-40.5)$ & ${ }^{*} 33.2(28.9-40.5)$ \\
& NOW & ${ }^{*} 23.4(14.8-25.7)$ & ${ }^{*} 20.6(14.8-22.7)$ & $23.2(17.2-26.6)$ & $20.9(16.0-27.5)$ \\
\hline
\end{tabular}

$\mathrm{EF}=$ Early Follicular; LF = Late Follicular; EL = Early Luteal; LL = Late Luteal; BF (\%) = Percentage of Body Fat. OW: BF (\%), ${ }^{*}$ p < 0.05. NOW: Weight, ${ }^{*} \mathrm{p}<0.05$; BMI, ${ }^{*} \mathrm{p}<0.05 ;{ }^{*} \mathrm{BF}(\%), \mathrm{p}<0.05$.

Table 2. Steroid hormones in obese $(\mathrm{OW}, \mathrm{N}=13)$ and non-obese women $(\mathrm{NOW}, \mathrm{N}=6)$ during the menstrual cycle: median (Minimum-Maximum).

\begin{tabular}{|c|c|c|c|c|c|}
\hline & & \multicolumn{4}{|c|}{ Menstrual Cycle } \\
\hline & & $\mathrm{EF}$ & LF & EL & LL \\
\hline \multirow{2}{*}{ FSH (mIU) } & OW & $6.2(3.6-15.0)$ & $6.6(3.9-23.3)$ & $7.6(4.1-8.7)$ & $6.2(0.1-13.0)$ \\
\hline & NOW & $6.1(4.1-9.3)$ & $10.0(3.5-12.5)$ & $7.0(0.6-12.1)$ & $8.0(4.6$ - 11.5) \\
\hline \multirow{2}{*}{ LH (mIU) } & OW & $1.8(0.02-6.9)$ & $3.8(0.2-19.3)$ & $5.0(1.2-19.2)$ & $6.2(0.08-25.5)$ \\
\hline & NOW & ${ }^{* *, *} 1.3(0.10-4.6)$ & ${ }^{* *} 11.0(1.9-28.5)$ & ${ }^{*} 15.7(4.8-50.4)$ & $5.9(3.4-7.8)$ \\
\hline \multirow{2}{*}{$\mathrm{P}_{4}(\mathrm{ng} / \mathrm{mL})$} & OW & ${ }^{* * * *} 0.41(0.04-4.6)$ & ${ }^{*, * *} 0.30(0.01-2.1)$ & ${ }^{* * *} 2.0(0.2-8.6)$ & ${ }^{* *} 8.6(0.7-14.4)$ \\
\hline & NOW & $0.24(0.13-0.81)$ & ${ }^{* *} 0.40(0.15-1.5)$ & ${ }^{*, * * *} 2.3(1.7-12.7)$ & *6.7 (1.0 - 9.6) \\
\hline \multirow{2}{*}{$\begin{array}{l}\text { Estradiol } \\
\text { (pg/mL) }\end{array}$} & OW & $8.3(52.4-368.04)$ & $164.2(70.9$ - 339.4) & $202.5(85.8$ - 368.2) & $135.9(29.8$ - 491.3) \\
\hline & NOW & *156.6 (76.1 - 201.7) & *175.5 (129.3 - 276.6) & $224(139-380.7)$ & 204.7 (98.6 - 330.8) \\
\hline \multirow{2}{*}{$\begin{array}{l}\text { T.Testosterone } \\
\text { (ng/dL) }\end{array}$} & OW & $0.07(0.01-0.22)$ & $0.07(0.01-0.28)$ & $0.13(0.01-0.33)$ & $0.11(0.02-0.26)$ \\
\hline & NOW & $0.05(0.01-0.06)$ & $0.15(0.01-0.29)$ & $0.10(0.02-0.26)$ & $0.08(0.05-0.11)$ \\
\hline \multirow{2}{*}{ SHBG (nmol/L) } & OW & ${ }^{* *} 73.7$ (39.2 - 174.1) & **,*56.2 (29.4 - 167.3) & ${ }^{* *} 63.3(30.6$ - 178.9) & ${ }^{* *, *} 71.9(39.2$ - 173.3) \\
\hline & NOW & *65.5 (52.1 - 114.7) & "51.5 (39.3 - 89.0) & ${ }^{*} 61.8(46.0-102.4)$ & *65.7 (52.2 - 114.2) \\
\hline
\end{tabular}

EF = Early Follicular; LF = Late Follicular; EL = Early Luteal; LL = Late Luteal; FSH = Follicle Stimulating Hormone; LH = Luteinizing Hormone; $\mathrm{P}_{4}=$ Progesterone; T. Testosterone = Total Testosterone; SHBG = Sex Hormone-Binding-Globulin; Significant differences were: ${ }^{*} \mathrm{p}<0.05$ and ${ }^{* * *} \mathrm{p}<$ 0.01 . 
related to FSH in the follicular phase $(\mathrm{p}<0.001)$ and to testosterone in the luteal phase $(\mathrm{p}<0.001)$. In NOW, leptin was inversely related to SHBG $(\mathrm{p}<0.001)$, and glucose $(\mathrm{p}=0.03)$. In Table 3 , the results of the regression analysis of the entire group of women are presented. The results show that leptin was directly related to BMI ( $<0.001)$ and inversely to SHBG $(\mathrm{p}<0.001)$.

In the luteal phase of the menstrual cycle, leptin was directly related to testosterone ( $p<0.001)$. Finally, as is shown in Table 4, the L-mRNA across the phases of the menstrual cycle was expressed with the following frequencies: EF, 1/7 (14.3\%); LF, 2/7 (28.6\%); EL, 1/7 (14.3\%); and LL, 3/7 (42.9\%). The OB-R mRNA was expressed with the following frequencies by phase: EF, 5/7 (71.4\%); LF, 1/7 (14.3\%); EL, 2/7 (28.6\%); and LL, $5 / 7$ (71.4\%).

These results suggest that L-mRNA expression and its receptor in subcutaneous human fat are regulated in a periodic way throughout the menstrual cycle, with greater expression in the late secretory phase in comparison to the follicular phase of the menstrual cycle.

Figure 2(a) shows a representative gel electrophoresis (patient IV), upon which we based our conclusions of presence of absence of the transcript using densitometry. Lanes 2 - 5 of 2.A contain for L-mRNA transcript isolated from samples taken during the EF, LF, EL and LL, respectively, and lanes 6 - 9 represent the assay for the OB-R mRNA receptor across these phases, respectively. Note that these data are recapitulated in row IV of Table 4 along the results of all of the gel electrophoresis analyses. Figure 2(b) shows our positive and negative controls, lanes 2 - 5 and 6 - 9, respectively. GDH corresponds to Glycerol-3-Phosphate-Dehydrogenase (GDH) mRNA (lanes 2 - 5) and samples WO/RT shows the results without reverse transcriptase (lanes 6 - 9).

Along with our other findings, the L-mRNA and OB-R-mRNA expression patterns demonstrated by the results of the gel electrophoresis show that in human subcutaneous fat tissue, leptin and its receptor have higher expression levels in the late secretory phase of the menstrual cycle.

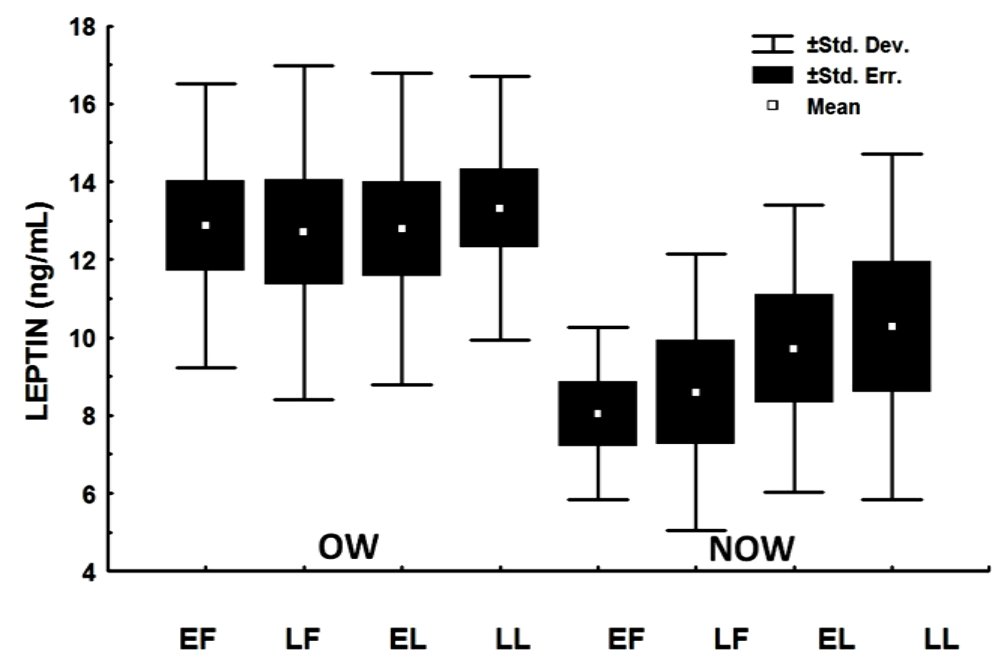

Figure 1. Leptin serum levels in obese women (left), and non-obese women (right). $\mathrm{EF}=$ Early Follicular Phase; LF = Late Follicular Phase; EL = Early Luteal Phase; and LL = Late Luteal Phase. The results for ANOVA, comparing the eight groups were: $\mathrm{F}=2.7, \mathrm{p}=0.02$.

Table 3. Results of multiple regression analysis showing correlation of leptin with hormones and anthropometric variables.

\begin{tabular}{ccccc}
\hline Dependent Variable Leptin & Independent Variable & $\beta$ & $t$ & p \\
All menstrual cycle phases & SHBG & -0.41 & -4.7 & $<0.001$ \\
$\left(\mathrm{R}^{2}=0.6\right)$ & $\mathrm{A} / \mathrm{H}$ & -0.46 & -4.2 & $<0.001$ \\
& $\mathrm{BMI}$ & 0.72 & 6.5 & $<0.001$ \\
Luteal phase $\left(\mathrm{R}^{2}=0.51\right)$ & Testosterone & 0.71 & 3.9 & $<0.001$ \\
\hline
\end{tabular}

SHBG = Sex Hormone-Binding Globulin, BMI = Body Mass Index, A/H = Abdomen to hip ratio. 


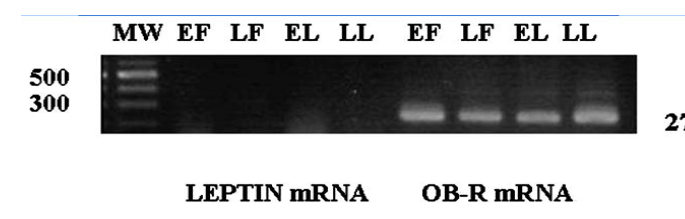

(a)
500

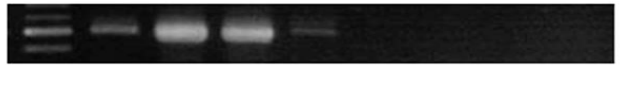

GDH
WO/RT

(b)

Figure 2. Representative gel used to determine the presence or absence of leptin and OBR mRNA transcripts, taken from subject IV. The upper picture (a) corresponds to leptin mRNA (lanes 2 - 5) and OB-R mRNA (lanes 6 - 9). We used the Glycerol-3-Phosphate-Dehydrogenase (GDH) mRNA (lanes 2 - 5) as the positive control and samples without reverse transcriptase $(\mathrm{WO} / \mathrm{RT})$ (lanes 6 - 9) the negative control. EF = Early Follicular; LF = Late Follicular; EL = Early Luteal; LL = Late Luteal.

Table 4. Expression of leptin and leptin receptor messenger ribonucleic acid (OB-R mRNA) in subcutaneous (periumbilical) human fat tissue of obese and non-obese women.

\begin{tabular}{|c|c|c|c|c|c|c|c|c|c|}
\hline \multirow{2}{*}{ Subject } & \multicolumn{4}{|c|}{ Leptin mRNA } & \multicolumn{4}{|c|}{$O B-R$ mRNA } & \multirow{2}{*}{$\begin{array}{c}\mathrm{BMI} \\
\mathrm{Kg} / \mathrm{m}^{2}\end{array}$} \\
\hline & $\mathrm{EF}$ & LF & EL & LL & LL & $\mathrm{EF}$ & LF & EL & \\
\hline I & - & - & - & + & + & - & - & + & 27 \\
\hline II & - & - & - & - & - & - & + & + & 27 \\
\hline III & - & + & + & + & - & - & - & + & 37 \\
\hline IV & - & - & - & - & + & + & + & + & 35 \\
\hline $\mathrm{V}$ & - & - & - & - & + & - & - & + & 35 \\
\hline VI & + & + & - & - & + & - & - & - & 19 \\
\hline VII & - & - & - & + & + & - & - & - & 25 \\
\hline
\end{tabular}

EF = Early Follicular; LF = Late Follicular; EL = Early Luteal; LL = Late Luteal. Staining intensity: $(+)=$ Strong staining; $(-)=$ no staining. BMI = Body mass index.

\section{Discussion}

To the best of our knowledge, this is the first study demonstrating differences in leptin protein and leptin receptor OB-R mRNA expression in human subcutaneous abdominal fat tissue across the four phases of the physiological menstrual cycle. The incidence of OB-R mRNA expression in the subjects from which the biopsies were taken was high in the late secretory phase (71\%) and early follicular phase (also 71\%), of the menstrual cycle. In contrast, L-mRNA was expressed in $43 \%$ of subjects in the late secretory phase and in $14 \%$ of subjects in the early follicular phases. These results indicate that L-mRNA and OB-R mRNA expression of leptin and its receptor in subcutaneous human fat is regulated in a periodic manner throughout the menstrual cycle, with greater expression in the late secretory and early follicular phases of the menstrual cycle. Our results are based on the analysis of L-mRNA and OB-R mRNA levels which were taken from 28 human subcutaneous tissue biopsies from seven women, six of whom were considered obese by the parameters established in by the WHO. These women were each evaluated four times during one full menstrual cycle, once during each phase.

Montague et al. [13] demonstrated that L-mRNA levels were higher in subcutaneous adipose tissue than in omental adiposities, and that the subcutaneous-to-omental ratio of L-mRNA expression was markedly higher in women than in men. Thus, L-mRNA is expressed primarily by subcutaneous adiposities, particularly in women. Alfer et al. [7], demonstrated that the leptin receptor protein is expressed in glandular and luminal epithelium of human endometrial tissue. Their results, which are similar but not identical to ours, showed expression primarily in the follicular and mid-secretory phases of the menstrual cycle. In our study, we demonstrated that the L-mRNA and the OB-R mRNA was expressed in the greatest number of individuals during the late secretory and early follicular phase of the menstrual cycle. Kitawaki et al. [6], examined the expression of leptin and the leptin receptor in human endometrial tissue, and demonstrated that leptin receptor expression peaked in the early secretory phase of the menstrual cycle. This finding suggests that steroid hormones play a role in the modulation 
of leptin and the OB-R mRNA expression in subcutaneous abdominal fat tissue. Other investigators have demonstrated that in menstruating women, plasma leptin increases from the baseline through the early follicular phase to the mid-secretory phase, and returns to the baseline during menstruation [14], which gives further support to our conjecture that steroids play a role in the regulation of leptin expression.

In our study evaluating obese and non-obese women during one menstrual cycle, we observed that non-obese women had significant increases in weight, BMI and leptin serum levels in the late secretory phase of the menstrual cycle, yet these findings were not observed in obese women, in who neither BMI nor leptin serum levels changed significantly during the menstrual cycle. These findings suggest that obese and non-obese women have different regulatory mechanisms for leptin protein expression. This hypothesis is strengthened by our finding that in obese women, there is a strong direct relationship between leptin and testosterone levels in the luteal phase and with FSH levels in the follicular phase of the menstrual cycle, which was not observed in non-obese women. In the NOW, leptin levels were inversely related to SHBG and directly to glucose concentration. Ludwing et al. [15], evaluated the ovulatory cycles of 16 endocrinologically (and non-obese) normal volunteers, and found that mean leptin values during the luteal phase were significantly higher $(16.67 \pm 9.45 \mathrm{ng} / \mathrm{mL})$ than in the follicular phase $(13.50 \pm 8.75 \mathrm{ng} / \mathrm{mL})(\mathrm{p}<0.02)$. These investigators also demonstrated a strong direct relationship between leptin and the progression of the menstrual cycle $(r=0.91)$. Wunder et al. [16], evaluated the ovulatory cycles of 36 healthy, young, normoandrogenic women with normal body mass index, by measuring sex hormone levels every 1 - 2 days during one full cycle. Their findings indicate significant correlation during the follicular phase between leptin and prolactin and between leptin and free testosterone. These investigators concluded that leptin levels change during the menstrual cycle and that leptin levels are most stable on days 1 - 5 of the cycle. In another study, Lin et al. [17], administrated intravenous injections of $20 \mathrm{mg}$ conjugated estrogen (premarin) in 18 women with normal menstrual cycles on the fifth day of their cycle in order to evaluate whether or not estrogen affects levels of leptin and GnRH. They found that both the mean plasma levels of estrone, estradiol, were significantly increased four hours after injection and these significantly elevated levels were sustained for up to 72 hours after the injection of premarin. Significant increases in leptin and GnRH levels were observed when serum levels were tested at 28, 32, and 48 hours after injection, while the hormone levels of control subjects remained constant during this time. The mean LH and FSH levels had significantly increased by hours 56 and 72 after premarin administration. Similar to the results of this study, our findings demonstrate that in obese women, leptin is directly related to FSH during the follicular phase $(\mathrm{p}<0.001)$, and to testosterone in the late luteal phase $(\mathrm{p}<0.001)$. Our findings lead us to concur with Lin et al. [17], in their assertion that leptin must be somehow involved in the positive feedback regulation mechanism of estrogen by conveying a metabolic signal affecting the release of GnRH in hypothalamus, while its participation in the modulation of negative feedback remains unknown. However, whether or not leptin participates in the modulation of negative feedback mechanisms remains unknown.

Our finding of the direct relationship between testosterone and leptin serum levels during the luteal phase are similar of those reported by Wunder et al. [16] but are contradictory to those of Callies et al. [18], who found that in women with adrenal insufficiency (24 individuals), DHEA replacement led to a significant decrease in serum leptin (an indirect relationship) as compared to the placebo. Their study also demonstrated that a physiological DHEA replacement dose did not induce any significant changes in body mass index, body composition, or exercise capacity. In another study, Isidori et al. [19], studied 38 men (28 obese and 10 age-matched non- obese subjects) and demonstrated that leptin and fat mass are both inversely related to total and free testosterone levels. They also found that in obese males, androgen levels decline in proportion to the degree of obesity. Because of the apparent disparity between these and our findings, more studies are needed to clarify the relationship between testosterone and leptin expression during the secretory phase of the menstrual cycle in obese women.

The cause of the increase in plasma leptin concentration during some phases of the menstrual cycle has not yet been identified [16]. However, the effects of leptin on the hypothalamus, pituitary, and ovaries in humans have been well described [20]-[23]. Additionally, administration of leptin to normal female mice accelerates puberty [24], and in humans higher leptin levels have been shown to correlate to an earlier age at menarche [3]. Andrelli et al. [25], in a study of two patients with lipoatrophic diabetes that occurred before the onset of puberty, described that menarche occurred between 11 - 12 years of age, and was followed by regular menstrual cycles. One of those patients was subsequently able to become pregnant three times. Because of these findings, the investigators concluded that puberty and fertility can occur despite chronic low serum levels of leptin [25], 
and that leptin is therefore non-essential for normal reproductive function in humans.

Physiological responses to leptin are considered to be mediated mainly through the brain receptor OB-R. However, both the mRNA and the leptin protein itself, as well as OB-R mRNA and its protein are expressed in peripheral non-reproductive tissues as well. Our results, which are similar to those of Kitawaki et al. [6], demonstrated that the expression of leptin receptor mRNA peaks in the secretory phase of the menstrual cycle. The variation in mRNA expression levels during the menstrual cycle suggests that the expression of these genes is regulated by ovarian steroid hormones.

\section{Conclusion}

In conclusions, our results are based on the analysis of L-mRNA and OB-R mRNA obtained from 28 human subcutaneous tissue biopsies from women evaluated four times during one full menstrual cycle, in conjunction with the results of tests for reproductive hormone levels. Together, our data indicate that L-mRNA and OB-R MRNA expression are regulated in a periodic way throughout the menstrual cycle, with peaks of expression in the late secretory and early follicular phases. The physiological significance of high leptin serum levels during the secretory phase is unknown; as is the role of testosterone in the regulation L-mRNA and OB-R mRNA expression of the leptin and the leptin receptor during secretory phase of the menstrual cycle in obese women, but it is important that these relationships are clarified via further studies.

\section{Acknowledgements}

To Dr. Barry Komisaruk, from the Psychology Department of Rutgers The State University of New Jersey, for the support and help in the translation of the manuscript.

\section{References}

[1] Sorensen, T.I., Echwald, S. and Holm, J.C. (1996) Leptin in Obesity. BMJ, 313, 953-954. http://dx.doi.org/10.1136/bmj.313.7063.953

[2] Haffner, S.M., Stern, M.P., Miettinen, H., Wei, M. and Gingerich, R.L. (1996) Leptin Concentrations in Diabetic and Nondiabetic Mexican-Americans. Diabetes, 45, 822-824. http://dx.doi.org/10.2337/diab.45.6.822

[3] Matkovic, V., Ilich, J.Z., Skugor, M., Badenhop, N.E., Goel, P., Clairmont, A., et al. (1997) Leptin Is Inversely Related to Age at Menarche in Human Females. The Journal of Clinical Endocrinology \& Metabolism, 82, 3239-3245.

[4] Brzechffa, P.R., Jakimiuk, A.J., Agarwal, S.K., Weitsman, S.R., Buyalos, R.P. and Magoffin, D.A. (1996) Serum Immunoreactive Leptin Concentrations in Women with Polycystic Ovary Syndrome. The Journal of Clinical Endocrinology \& Metabolism, 81, 4166-4169.

[5] Butte, N.F., Hopkinson, J.M. and Nicolson, M.A. (1997) Leptin in Human Reproduction: Serum Leptin Levels in Pregnant and Lactating Women. The Journal of Clinical Endocrinology \& Metabolism, 82, 585-589. http://dx.doi.org/10.1210/jcem.82.2.3731

[6] Kitawaki, J., Koshiba, H., Ishihara, H., Kusuki, I., Tsukamoto, K. and Honjo, H. (2000) Expression of Leptin Receptor in Human Endometrium and Fluctuation during the Menstrual Cycle. The Journal of Clinical Endocrinology \& Metabolism, 85, 1946-1950. http://dx.doi.org/10.1210/jcem.85.5.6567

[7] Alfer, J., Muller-Schottle, F., Classen-Linke, I., Von-Rango, U., Happel, L., Beier-Hellwig, K., et al. (2000) The Endometrium as a Novel Target for Leptin: Differences in Fertility and Subfertility. Molecular Human Reproduction, 6, 595-601. http://dx.doi.org/10.1093/molehr/6.7.595

[8] Pollock, M.L. and Jackson, A.S. (1984) Research Progress in Validation of Clinical Methods of Assessing Body Composition. Medicine \& Science in Sports \& Exercise, 16, 606-615. http://dx.doi.org/10.1249/00005768-198412000-00016

[9] Kabir, I., Malek, M.A., Rahman, M.M., Khaled, M.A. and Mahalanabis, D. (1994) Changes in Body Composition of Malnourished Children after Dietary Supplementation as Measured by Bioelectrical Impedance. The American Journal of Clinical Nutrition, 59, 5-9.

[10] Jin, L., Burguera, B.G., Couce, M.E., Scheithauer, B.W., Lamsan, J., Eberhardt, N.L., et al. (1999) Leptin and Leptin Receptor Expression in Normal and Neoplastic Human Pituitary: Evidence of a Regulatory Role for Leptin on Pituitary Cell Proliferation. The Journal of Clinical Endocrinology \& Metabolism, 84, 2903-2911.

[11] Luoh, S.M., Di Marco, F., Levin, N., Armanini, M., Xie, M.H., Nelson, C., et al. (1997) Cloning and Characterization of a Human Leptin Receptor Using a Biologically Active Leptin Immunoadhesin. Journal of Molecular Endocrinology, 18, 77-85. http://dx.doi.org/10.1677/jme.0.0180077 
[12] Tokunaga, K., Nakamura, Y., Sakata, K., Fujimori, K., Ohkubo, M., Sawada, K., et al. (1987) Enhanced Expression of a Glyceraldehyde-3-phosphate Dehydrogenase Gene in Human Lung Cancers. Cancer Research, 47, 5616-5619.

[13] Montague, C.T., Prins, J.B., Sanders, L., Digby, J.E. and O’Rahilly, S. (1997) Depot- and Sex-Specific Differences in Human Leptin mRNA Expression: Implications for the Control of Regional Fat Distribution. Diabetes, 46, 342-347. http://dx.doi.org/10.2337/diab.46.3.342

[14] Riad-Gabriel, M.G., Jinagouda, S.D., Sharma, A., Boyadjian, R. and Saad, M.F. (1998) Changes in Plasma Leptin during the Menstrual Cycle. European Journal of Endocrinology, 139, 528-531. http://dx.doi.org/10.1530/eje.0.1390528

[15] Ludwig, M., Klein, H.H., Diedrich, K. and Ortmann, O. (2000) Serum Leptin Concentrations throughout the Menstrual Cycle. Archives of Gynecology and Obstetrics, 263, 99-101. http://dx.doi.org/10.1007/s004040050004

[16] Wunder, D.M., Yared, M., Bersinger, N.A., Widmer, D., Kretschmer, R. and Birkhauser, M.H. (2006) Serum Leptin and C-Reactive Protein Levels in the Physiological Spontaneous Menstrual Cycle in Reproductive Age Women. European Journal of Endocrinology, 155, 137-142. http://dx.doi.org/10.1530/eje.1.02178

[17] Lin, K.C., Sagawa, N., Yura, S., Itoh, H. and Fujii, S. (2005) Simultaneous Increases of Leptin and GonadotropinReleasing Hormone Following Exogenous Estrogen Administration in Women with Normally Menstrual Cycle. Endocrine Journal, 52, 449-454. http://dx.doi.org/10.1507/endocrj.52.449

[18] Callies, F., Fassnacht, M., Van Vlijmen, J.C., Koehler, I., Huebler, D., Seibel, M.J., et al. (2001) Dehydroepiandrosterone Replacement in Women with Adrenal Insufficiency: Effects on Body Composition, Serum Leptin, Bone Turnover, and Exercise Capacity. The Journal of Clinical Endocrinology \& Metabolism, 86, 1968-1972. http://dx.doi.org/10.1210/jcem.86.5.7483

[19] Isidori, A.M., Caprio, M., Strollo, F., Moretti, C., Frajese, G., Isidori, A., et al. (1999) Leptin and Androgens in Male Obesity: Evidence for Leptin Contribution to Reduced Androgen Levels. The Journal of Clinical Endocrinology \& Metabolism, 84, 3673-3680.

[20] Cioffi, J.A., Van Blerkom, J., Antczak, M., Shafer, A., Wittmer, S. and Snodgrass, H.R. (1997) The Expression of Leptin and Its Receptors in Pre-Ovulatory Human Follicles. Molecular Human Reproduction, 3, 467-472. http://dx.doi.org/10.1093/molehr/3.6.467

[21] Dieterich, K.D. and Lehnert, H. (1998) Expression of Leptin Receptor mRNA and the Long Form Splice Variant in Human Anterior Pituitary and Pituitary Adenoma. Experimental and Clinical Endocrinology \& Diabetes, 106, 522-525. http://dx.doi.org/10.1055/s-0029-1212027

[22] Baskin, D.G., Schwartz, M.W., Seeley, R.J., Woods, S.C., Porte Jr., D., Breininger, J.F., et al. (1999) Leptin Receptor Long-Form Splice-Variant Protein Expression in Neuron Cell Bodies of the Brain and Co-Localization with Neuropeptide Y mRNA in the Arcuate Nucleus. Journal of Histochemistry \& Cytochemistry, 47, 353-362. http://dx.doi.org/10.1177/002215549904700309

[23] Di Carlo, C., Tommaselli, G.A., De Filippo, E., Pisano, G., Nasti, A., Bifulco, G., et al. (2002) Menstrual Status and Serum Leptin Levels in Anorectic and in Menstruating Women with Low Body Mass Indexes. Fertility and Sterility, 78, 376-382. http://dx.doi.org/10.1016/S0015-0282(02)03221-1

[24] Ahima, R.S., Dushay, J., Flier, S.N., Prabakaran, D. and Flier, J.S. (1997) Leptin Accelerates the Onset of Puberty in Normal Female mice. The Journal of Clinical Investigation, 99, 391-395. http://dx.doi.org/10.1172/JCI119172

[25] Andreelli, F., Hanaire-Broutin, H., Laville, M., Tauber, J.P., Riou, J.P. and Thivolet, C. (2000) Normal Reproductive Function in Leptin-Deficient Patients with Lipoatropic Diabetes. The Journal of Clinical Endocrinology \& Metabolism, 85, 715-719. http://dx.doi.org/10.1210/jcem.85.2.6392 
Scientific Research Publishing (SCIRP) is one of the largest Open Access journal publishers. It is currently publishing more than 200 open access, online, peer-reviewed journals covering a wide range of academic disciplines. SCIRP serves the worldwide academic communities and contributes to the progress and application of science with its publication.

Other selected journals from SCIRP are listed as below. Submit your manuscript to us via either submit@scirp.org or Online Submission Portal.
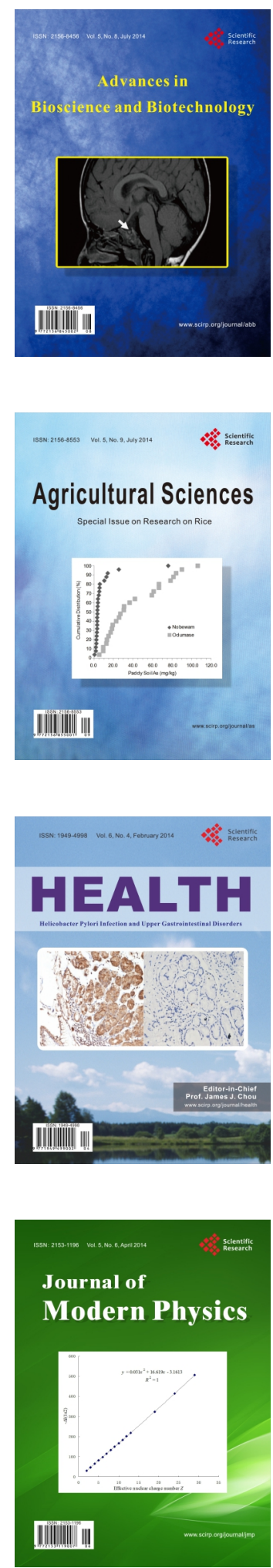
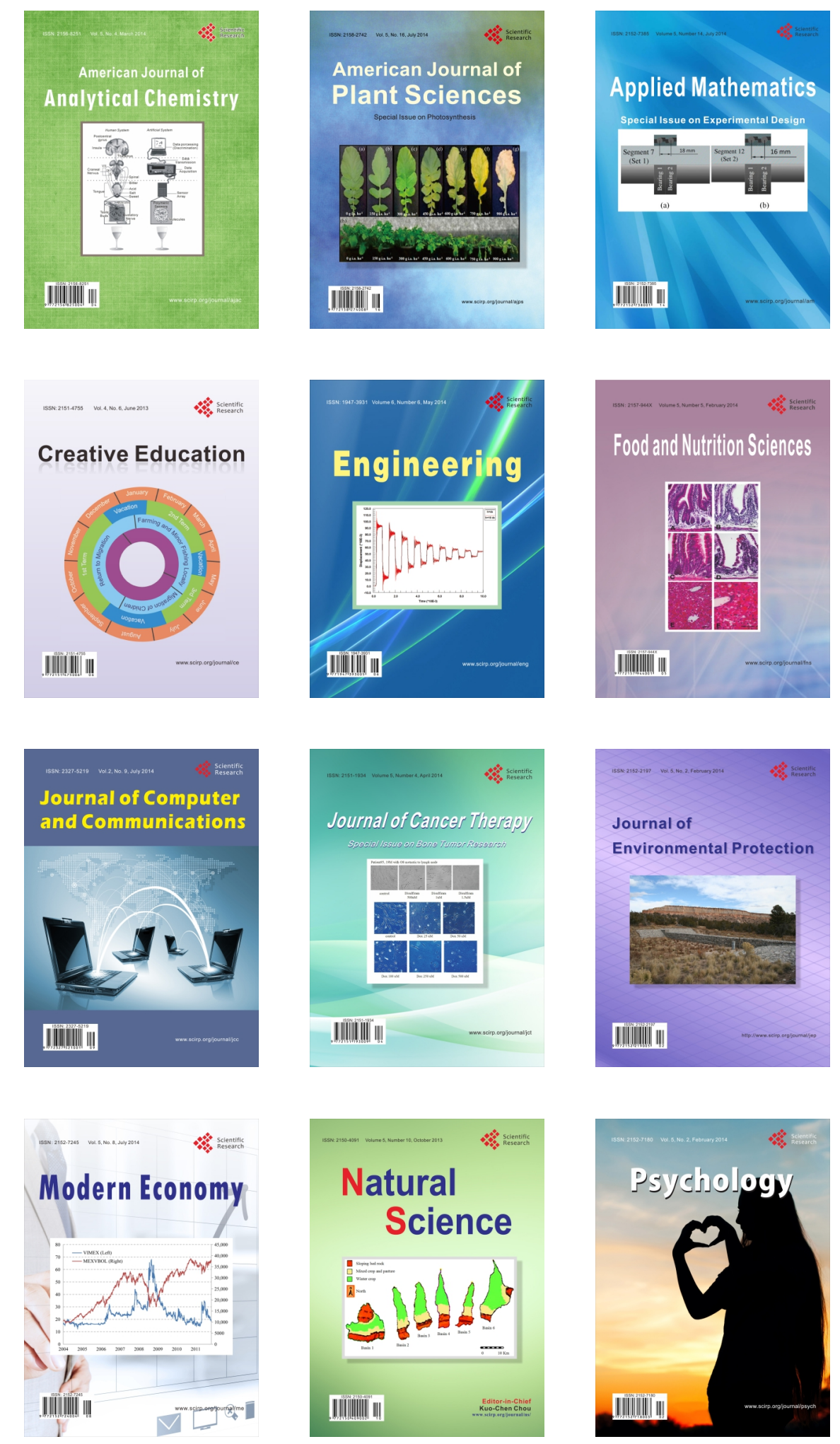